\title{
Wnt/ß-Catenin Signaling: a Promising New Target for Fibrosis Diseases
}

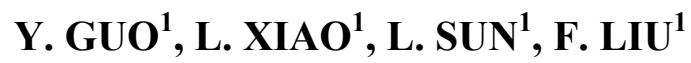 \\ ${ }^{1}$ Department of Nephropathy, Second Xiangya Hospital, Central South University, Changsha, \\ P. R. China
}

Received November 16, 2011

Accepted April 26, 2012

On-line June 6, 2012

\begin{abstract}
Summary
$\mathrm{Wnt} / \beta$-catenin signaling is involved in virtually every aspect of embryonic development and also controls homeostatic selfrenewal in a number of adult tissues. Recently, emerging evidence from researches of organ fibrosis suggest that sustained $\mathrm{Wnt} / \beta$-catenin pathway reactivation is linked to the pathogenesis of fibrotic disorders. Here we focus on $W n t / \beta$-catenin-related pathogenic effects in different organs, such as lung fibrosis, liver fibrosis, skin fibrosis and renal fibrosis. Additionally, $W n t / \beta-$ catenin signaling works in a combinatorial manner with TGF- $\beta$ signaling in the process of fibrosis, and TGF- $\beta$ signaling can induce expression of $\mathrm{Wnt} / \beta$-catenin superfamily members and vice versa. Moreover, network analysis, based on pathway databases, revealed that key factors in the Wnt pathway were targeted by some differentially expressed microRNAs detected in fibrosis diseases. These findings demonstrated the crosstalks between $W n t / \beta$-catenin pathway and TGF- $\beta$ signalings, and microRNAs, highlighting the role of Wnts in organ fibrogenesis. Most importantly, nowadays there is a variety of Wnt pathway inhibitors which give us the potential therapeutic feasibility, modulation of the Wnt pathway may, therefore, present as a suitable and promising therapeutic strategy in the future.
\end{abstract}

\section{Key words}

Wnt $\bullet \beta$-catenin $\bullet$ Fibrosis $\bullet$ TGF- $\beta \bullet$ MicroRNA

\section{Corresponding authors}

L. Sun and F. Liu, Department of Nephrology, Second Xiangya Hospital, Central South University, Changsha, Hunan Province, 410011, P. R. China. Fax: 86731 5292064. E-mail: sunlinnwu11@163.com and Ifymh@yahoo.cn

\section{Introduction}

Fibrosis is a complex response initiated to protect the host from an injurious event; however, it leads to massive deposition of matrix, disruption of the normal tissue architecture, and parenchymal destruction when it becomes independent from the initiating stimulus (Franklin 1997). Many pathways and cytokines were found take part in this process, like TGF- $\beta / \mathrm{Smad}$, PI3K/Akt, p38 MAPK, etc. However, the molecular mechanism is still not well defined yet and no effective treatment has been found. Thus, exploration of new signal pathways and development of new therapeutic strategies is urgently needed.

$\mathrm{Wnt} / \beta$-catenin is an evolutionarily conserved cellular signaling system that plays an essential role in diverse arrays of biologic processes such as organogenesis, tissue homeostasis, and pathogenesis of many human diseases (Clevers 2006). Recent studies have demonstrated that aberrant $\mathrm{Wnt} / \beta$-catenin signaling pathway plays a key role in the development of organ fibrosis, suggesting it may be a novel therapeutic target in fibrotic disorders (Cheng et al. 2008, He et al. 2009, Kim et al. 2011).

\section{Wnt/ $\beta$-catenin signaling}

The Wnt family proteins are secreted lipid-modified glycoproteins and exert their function through at least three known pathways, the canonical one of which is Wnt/ $\beta$-catenin signaling pathway (Chien et al. 2009). 


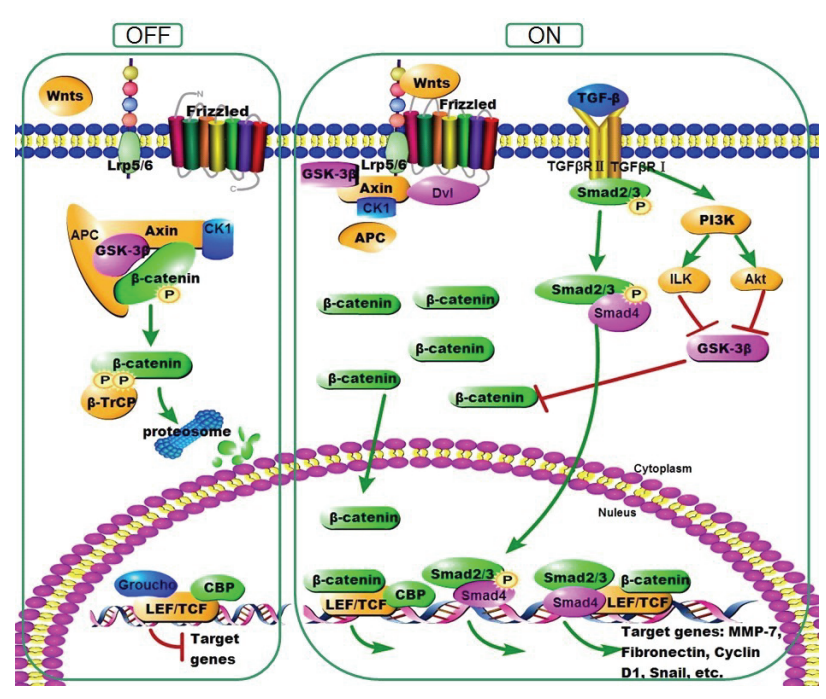

Fig. 1. Overview of $W n t / \beta-C a t e n i n$ Signaling. Without $W n t$ ligands, cytoplasmic $\beta$-catenin is phosphorylated by a destruction complex which is composed of Axin, adenomatous polyposis coli protein (APC), casein kinase 1 (CK1) and glycogen synthase

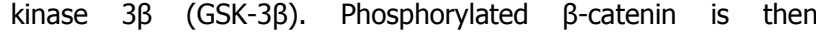
ubiquitinated by the $\beta$-transducin repeat-containing protein $(\beta-\operatorname{TrCP})$, a component of E3 ubiquitin ligase complex, and destructed by the proteasome ultimately. Once activated, Wnt proteins bind to their receptors and induce a series of downstream signaling events which lead to the disassembly of the destruction complex, resulting in dephosphorylation of $\beta$-catenin. Accumulated $\beta$-catenin then translocates into the nucleus, where they bind to $T$ cell factor (TCF)/Lymphoid enhancer-binding factor (LEF) to stimulate the transcription of Wnt target genes, including fibrosis-related gene expression, such as Fibronectin, Matrix Metallo Proteinases-7 (MMP-7), Twist and Snail. In addition, $W n t / \beta$-Catenin and TGF- $\beta$ signaling converge at the promoter, where Smads, $\beta$-Catenin, and LEF/TCF form a complex to coregulate specific genes expression. $\beta$-catenin is further stabilized in the cytoplasm by the action of TGF- $\beta$ to signal through phosphatidyl inositol 3-kinase (PI3K). PI3K can then signal integrin-linked kinase (ILK) and AKT, which can phosphorylate and inactivate GSK-3ß.

$\beta$-catenin is a key regulator in this signaling, where cytoplasmic $\beta$-catenin translocate into the nucleus and then bind to $\mathrm{T}$ cell factor (TCF)/Lymphoid enhancerbinding factor (LEF) to stimulate the transcription of Wnt target genes, including fibrosis-related gene expression, such as Fibronectin, Matrix Metallo Proteinases-7 (MMP-7), Plasminogen activator inhibitor-1 (PAI-1), Twist and Snail. Wnt proteins transmit their signal across the plasma membrane through interacting with the Fzd family of proteins and members of LRP5/6 (Fig. 1). Under resting condition, without Wnt ligands, cytoplasmic $\beta$-catenin is phosphorylated by a destruction complex which is composed of axin, adenomatous polyposis coli protein (APC), and glycogen synthase kinase (GSK)-3 $\beta$, and then ubiquitinated and destructed by the proteasome ultimately. Once activated, Wnt proteins bind to their receptors and lead to the

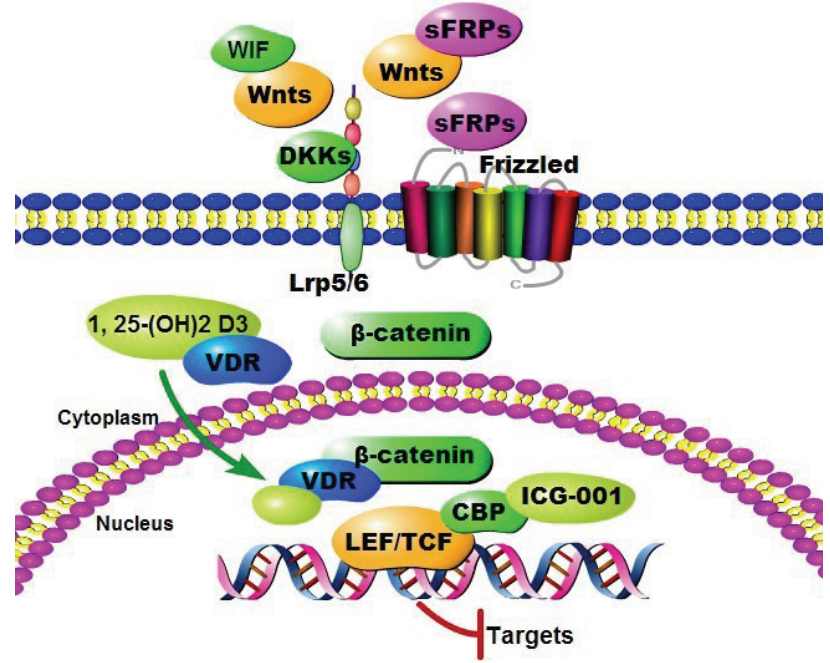

Fig. 2. Antagonists and inhibitors of $W n t / \beta$-Catenin Signaling. DKKs: Dickkopf 1-4, bind to Lrp5/6; sFRPs: secreted Frizzledrelated proteins, bind to Wnt ligands and Frizzled receptors; WIF: Wnt inhibitory factor; VDR: Vitamin $D$ receptor, ligand-activated VDR binds to $\beta$-catenin competing with TCF-4; CBP: Cyclic AMP response element binding protein (CREB)-binding protein; ICG-001: A small molecule inhibits TCF/ $\beta$-catenin transcription through interacting with CBP. See text for details.

disassembly of the destruction complex, resulting in dephosphorylation of $\beta$-catenin, thereby allowing $\beta$-catenin to accumulate in the cytosol and enter the nucleus (Fig. 1) (MacDonald et al. 2007, Huang and He 2008, He et al. 2012). The Wnt pathway has unique transcriptional outputs, which are determined by the developmental identity of the responding cell, instead of the nature of the signal. That is to say, the majority of Wnt target genes appear to be cell type specific (Cadigan and Liu 2006).

Several secreted protein families antagonize $\mathrm{Wnt} / \beta$-catenin signaling. The function of Wnt inhibitors depends on their expression levels and the cellular context. The secreted Frizzled-related proteins (sFRPs) and Wnt inhibitory factor (WIF), which exhibit a high degree of homology with the Wnt ligand-binding domains of Fzd, both bind to Wnt ligands, and thereby function as Wnt antagonists for both $\beta$-catenin and noncanonical signaling (Bovolenta et al. 2008). The secreted Dickkopf (DKK) family (DKK1-4), exemplified by DKK1, induce the LRP5/6 internalization and inactivation through binding to the second class receptor Kremen (KRM), and subsequently inhibiting the formation of the receptor complex (Fig. 2) (Mao et al. 2002).

$\mathrm{Wnt} / \beta$-catenin signaling is known to regulate cell-fate decisions during development, cell differentiation, and proliferation and death events 
(Grigoryan et al. 2008). It was found that aberrant expression of $\mathrm{Wnt} / \beta$-catenin signaling is involved in many diseases, such as tumor formation, hereditary disorders and fibrosis diseases (Clevers 2006).

\section{Role of Wnt/ $\beta$-catenin signaling in fibrosis diseases}

Wnt/ $\beta$-catenin signaling pathway is essential to embryonic development in general and organ morphogenesis, so it is not surprising that dysregulation of this pathway in adult has been linked to fibroblast biology and fibrosis. Recent researches have demonstrated that $\mathrm{Wnt} / \beta$-catenin signaling play a role in severe fibrotic diseases, such as pulmonary fibrosis, liver fibrosis, skin fibrosis and renal fibrosis.

\section{Wnt/ $\beta$-catenin signaling in pulmonary fibrosis}

Idiopathic pulmonary fibrosis (IPF), the most common form of pulmonary fibrosis, is characterized initially by alveolar epithelial cell injury followed by EMT and exaggerated fibroblast migration, activation, and proliferation with extracellular matrix remodeling (Noble 2003). Unbiased microarray screens have revealed the overexpression of Wnt genes, including Wnt2 and 5a, Fzd7 and 10, along with sFRP1 and 2 in IPF lungs compared with normal lungs or those with other interstitial lung diseases (Kaminski and Rosas 2006, Selman et al. 2006, 2008). More importantly, nuclear $\beta$-catenin immunoreactivity and abnormal levels of cyclin-D1 and matrilysin were demonstrated in proliferative bronchiolar lesions (basal-cell hyperplasia, squamous metaplasia, bronchiolization and honeycombing) of IPF patients (Chilosi et al. 2003). Interestingly, nuclear $\beta$-catenin accumulation was also demonstrated in fibroblast foci in most IPF samples, often associated with bronchiolar lesions, and similar results were showed in experimental lung fibrosis (Chilosi et al. 2003, Liu et al. 2009). In a subsequent study, Wnt1, 7b and 10b, Fzd2 and 3, $\beta$-catenin, and LEF1 expression significantly increased in IPF patients, and Wnt1, Wnt3a, $\beta$-catenin, and GSK- $3 \beta$ localized largely to alveolar and bronchial epithelium, and this was confirmed by qRT-PCR of primary alveolar epithelial type II (ATII) cells. In addition, functional in vitro studies revealed that Wnt3a induced lung epithelial cell proliferation and (myo)fibroblast activation and collagen synthesis (Konigshoff et al. 2008). Moreover, the antagonisms DKK1-4 were also reported express in hyperplastic alveolar epithelial cells in IPF patients, and DKK1 predominantly localized in basal bronchial epithelial cells (Pfaff et al. 2011). Additionally, nuclear $\beta$-catenin was increased in systemic sclerosis (SSc) pulmonary fibrosis and promoted lung fibroblast migration and proliferation, and activation of the Wnt/ $\beta$-catenin signaling pathway by mechanical ventilation is associated with ventilator-induced pulmonary fibrosis in healthy lungs (Lam et al. 2011).

\section{Wnt/B-catenin signaling in liver fibrosis}

Liver fibrosis represents chronic wound repair and activated hepatic stellate cells (HSCs) are the most important source of extracellular matrix proteins during this fibrotic process. Although expression of $\beta$-catenin in cell-cell contacts of stellate cells is known, people are now beginning to investigate the role of $\mathrm{Wnt} / \beta$-catenin in stellate cell activation. Cheng et al. (2008) reported that Wnt3a and Wnt10b, Fzd receptor-1 and 2, LRP6, along with nuclear $\beta$-catenin and TCF DNA binding were remarkably increased in culture-activated HSCs compared with quiescent HSC, and high expression of DKK1 increased apoptosis of cultured HSCs. Besides, expression of Wnt and Fzd genes were also induced in HSCs isolated from experimental cholestatic liver fibrosis. Moreover, human HSCs were significantly activated by Wnt3a, while this was inhibited in SFRP1 overexpressing cells. At the same time, Wnt3a treatment obviously suppressed tumor necrosis factor-related apoptosis-inducing ligand (TRAIL) induced apoptosis in control HSCs versus sFRP1 over-expressing cells (Myung et al. 2007). Meanwhile, fibrotic changes of liver could be attenuated by Pokeweed antiviral protein (PAP), which is regarded as a strong negative regulator of Wnt $/ \beta$-catenin signaling, and PAP significantly reduced the expressions and distribution of $\alpha$-SMA and $\beta$-catenin in vivo and in vitro as well as cell viability (Li et al. 2011, Xiong et al. 2009). In contrast to the above-mentioned studies, DNA microarrays found no changes in the phosphorylation state or nuclear translocation of $\beta$-catenin between quiescent and activated rat HSCs (Jiang et al. 2006).

\section{Wnt/ß-catenin signaling in skin fibrosis}

Skin fibrosis occurs in various kinds of human diseases, most notably systemic sclerosis ( $\mathrm{SSc}$ ), or scleroderma. SSc is a systemic connective tissue disease, the characteristic of which in human skin consists of excess collagen deposition in the dermis with loss of 
appendages and associated adipose tissue (Wei et al. 2011). Over the last years, several groups have used microarray analyses to obtain RNA expression profiles of skin from SSc patients and mice (Gardner et al. 2006, Bayle et al. 2008). Gardner et al. (2006) provided evidence that there are changes in the Wnt pathway in SSc biopsy samples, including down-regulation of Wnt inhibitory factor 1, Frizzled-related protein, and Frizzled homolog 7, as well as up-regulation of sFRP4. Microarray gene expression in skin of Tight-skin (Tsk) mouse (an animal model of SSc) showed increased mRNA levels of several genes, including Wnt2, Wnt3a, Wnt9a, Wnt10b and Wnt11; Dapper homolog antagonist of $\beta$-catenin (DACT1) and DACT2; Wnt-induced secreted protein 2; and sFRP2 and sFRP4. In addition, application of Wnt3a to cultured fibroblasts increased the levels of Fbn-1 and collagen (Bayle et al. 2008). Moreover, transgenic mice expressing Wnt-10b showed progressive loss of subcutaneous adipose tissue accompanied by dermal fibrosis, and Wnt-10b infection of normal fibroblasts and preadipocytes resulted in blockade of adipogenesis and up-regulation of fibrotic gene expression, suggesting that Wnt-10b switches differentiation of mesenchymal cells toward myofibroblasts by inducing a fibrogenic transcriptional program while suppressing adipogenesis (Wei et al. 2011).

\section{Wnt/ $\beta$-catenin signaling in renal fibrosis}

Kidney is a typical organ that develops on the basic of interactions between epithelial and mesenchymal tissues, and many studies have proved that hyperactive Wnt/ $\beta$-catenin signaling in the glomeruli and tubulointerstitium is detrimental to the kidney.

It has been shown that most members of Wnt family and Fzd receptors were upregulated in the unilateral ureteral obstruction (UUO) model whose characteristic is progressive interstitial fibrosis and tubular atrophy. At the same time, obstruction led to a dramatic accumulation of $\beta$-catenin in the cytoplasm and nuclei of renal tubular epithelial cells, and numerous Wnt $/ \beta$-catenin target genes (MMP-7, fibronectin, Twist, c-Myc) were induced and the expression was closely correlated with renal $\beta$-catenin abundance. More importantly, delivery of Wnt antagonist DKK-1 gene significantly reduced renal $\beta$-catenin accumulation, inhibited the expression of $\mathrm{Wnt} / \beta$-catenin target genes and suppressed expression of type I collagen and fibronectin (He et al. 2009, 2012). In addition, levels of
MMP-7 protein detected in the urine correlated with renal Wnt/ $\beta$-catenin activity, suggesting it may be a noninvasive biomarker of this profibrotic signaling in the kidney (He et al. 2012). Moreover, administration of recombinant sFRP4 protein caused a reduction of $\beta$-catenin in tubular epithelial cells and suppressed the progression of renal fibrosis (Surendran et al. 2005). In addition, Wnt4 expression was induced by folic acid nephropathy and UUO in the mice, and the pattern of it during progression of renal fibrosis closely paralleled with that of MMP-7, suggesting that Wnt4 may regulate MMP-7 expression and take part in the pathogenesis of renal fibrosis (Surendran et al. 2004).

Podocyte dysfunction, one of the major causes of proteinuria, leads to glomerulosclerosis and end stage renal disease. Several studies showed that $\mathrm{Wnt} / \beta$-catenin signaling promotes podocyte dysfunction and albuminuria, and that blockade of this signaling can ameliorate albuminuria (Dai et al. 2009, Heikkila et al. 2010, He et al. 2011). Overexpression of Wnt1 in vivo activated glomerular $\beta$-catenin and aggravated albuminuria, whereas blockade of Wnt signaling with DKK1 ameliorated podocyte lesions. In addition, Podocyte specific knockout of $\beta$-catenin protected against development of albuminuria after injury and pharmacologic activation of $\beta$-catenin. More importantly, in human proteinuric kidney diseases such as diabetic nephropathy and focal segmental glomerulosclerosis, upregulation of Wntl and active $\beta$-catenin in podocytes were observed (Dai et al. 2009). Furthermore, decreased podocyte foot process effacement associated with slit diaphragm abnormalities was observed through electron microscope in ADR-treated $\beta$-catenin-deficient mice compared with control mice (Heikkila et al. 2010).

Autosomal dominant polycystic kidney disease (ADPKD) is common and is a major cause of renal failure. Transgenic mice that overproduce an oncogenic form of $\beta$-catenin in the epithelial cells of the kidney developed severe polycystic lesions soon after birth that affected the glomeruli, proximal, distal tubules and collecting ducts (Saadi-Kheddouci et al. 2001). In addition, the cell proliferation and apoptotic index increased remarkably in cystic tubules of the transgenic mice compared to that of littermate controls (SaadiKheddouci et al. 2001). Chronic allograft damage following kidney transplantation is also characterized by progressive fibrosis. Recent studies have shown that central components of $\mathrm{Wnt} / \beta$-catenin signaling (including Wnt3, LEF1 and $\beta$-catenin) were significantly 
upregulated with the development of chronic damage, and oral treatment with 13 cis retinoic acid (13cRA) selectively ameliorated the dysregulation of canonical Wnt pathway and led to a general preservation of cilial structures (von Toerne et al. 2009, 2011).

\section{Other fibrotic disorders and Wnt/ $\beta$-catenin signaling}

Besides the main organs, Wnt/ $\beta$-catenin signaling reactivation was also seen in rare fibrotic diseases. Intranuclear accumulation of $\beta$-catenin and LEF-1 was observed in the pterygial epithelium, which suggest $\beta$-catenin may play a key role in the pathogenesis of pterygium (Kato et al. 2007). Meanwhile, muscle stem cells from aged mice tend to convert from a myogenic to a fibrogenic lineage, and this conversion is associated with an activation of the $\mathrm{Wnt} / \beta$-catenin signaling and can be suppressed by Wnt inhibitors (Brack et al. 2007). Moreover, Wnt/ $\beta$-catenin signaling can expand the population of muscle resident stromal cells ( $\mathrm{mrSCs}$ ) and stimulate their production of collagen, and this can be inhibited by DKK1 (Trensz et al. 2010). Additionally, Cheng et al. (2010) proved that activation of vascular smooth muscle Parathyroid Hormone Receptor (PHR) can inhibit $\mathrm{Wnt} / \beta$-catenin signaling and reduce vascular oxidative stress, thus limiting aortic type I collagen and calcium accrual. Lastly, targeting GSK- $3 \beta$ potently induced dermal fibrosis by activation of the canonical Wnt pathway (Bergmann et al. 2011).

\section{Cross-talk between Wnt/ $\beta$-catenin and TGF- $\beta$ signaling}

Transforming growth factor- $\beta$ (TGF- $\beta$ ) is a key mediator of fibrosis progression, inducing epithelial-tomesenchymal trasnsition (EMT), fibroblast-tomyofibroblast activation, and extracellular matrix deposition (Biernacka et al. 2011). The cross-talk between TGF- $\beta$ and Wnt pathways has been known for a long time (Fig. 1) (Cheon et al. 2006, Willis and Borok 2007, Medici et al. 2008). In recent years, the cooperation of TGF- $\beta$ and Wnt/ $\beta$-catenin signaling in the process of fibrosis have been demonstrated (Eger et al. 2004, Sato 2006). Simultaneous inhibition of both TGF- $\beta$ and Wnt/ $\beta$-catenin pathways reverted mesenchymal cfos estrogen receptor (FosER) cells to a polarized epithelial phenotype, whereas inhibition of a single pathway caused only partial rescue of epithelial features, which indicates that both TGF- $\beta$ and Wnt $/ \beta$-catenin pathways cooperate in epithelial dedifferentiation during EMT (Eger et al.
2004). Additionally, expression of Wnt1, $\beta$-catenin and their target genes were upregulated in association with TGF- $\beta$-induced podocyte injury and proteinuria in vitro and in vivo, and this process was blocked by Wnt antagonist DKK1 (Wang et al. 2011). The activation of $\beta$-catenin mediated transcription induced by TGF- $\beta$ was shown via the Smad3 and p38MAPK pathways in human dermal fibroblasts (Sato 2006), and p- $\beta$-catenin $/ \mathrm{pSmad} 2$ complexes were observed in alveolar epithelial cells both in vitro and in vivo during the fibrotic phase, and most importantly, in the lung tissue from IPF patients (Kim et al. 2009). In addition, it was demonstrated that $\beta$-catenintargeted siRNA significantly decreased the level of TGF- $\beta$ expression in the lung tissue of bleomycinadministered mice, and loss and gain of DKK1 function modulated HG-induced TGF- $\beta$ expression (Lin et al. 2010, Kim et al. 2011). More recently, Zhou et al. (2012) found that interactions between $\beta$-catenin and TGF- $\beta$ signaling pathways mediate EMT are dependent on the transcriptional co-activator cAMP-response element binding protein (CREB)-binding protein (CBP). Finally, Masszi et al. (2004) showed that intercellular contact disassembly alone induced degradation of E-cadherin and $\beta$-catenin, but TGF- $\beta 1$ selectively rescued $\beta$-catenin and increased the level of free $\beta$-catenin. All those observations proved that $\mathrm{Wnt} / \beta$-catenin signaling works in a combinatorial manner with TGF- $\beta$ signaling in the process of fibrosis, and TGF- $\beta$ signaling can induce expression of $\mathrm{Wnt} / \beta$-catenin superfamily members and vice versa.

\section{Wnts and microRNAs}

MicroRNA dysregulation has been demonstrated participate in fibrotic disorders of late years. Interestingly, network analysis, based on pathway databases, revealed that key factors in the Wnt pathway were targeted by some differentially expressed microRNAs (DEmiRNAs) detected in the fibrosis diseases (Cho et al. 2010, Ezzie et al. 2011, Pandit et al. 2011, Xie et al. 2011). The potential targets include the members of the Wnt family, such as Wnt5a, Wnt7a, Wnt7b and Wnt9a, the receptors Fzd5 and Fzd8, and the molecules in the Wnt pathway such as GSK-3 $\beta$, APC, LEF, along with antagonists such as SFRP1 and 2 (Cho et al. 2010, Pandit et al. 2011, Xie et al. 2011). These findings confirmed the crosstalk between microRNAs and Wnt signaling, and provided a framework in the multilayer regulatory machinery in orchestrating 
microRNAs-Wnt signaling-cellular process to control tissue injury and fibrosis.

\section{Therapeutic strategies}

Given increasing activity of the Wnt $/ \beta$-catenin signaling has been implicated in the pathogenesis of different fibrotic diseases, methods for decreasing this signaling are required and would have strong clinical implications. There are different ways to inhibit Wnt/ $\beta$-catenin signaling, such as, application of soluble receptors, usage of antagonists, administration of siRNA, and chemically synthesized transcription factor competitor and transcription inhibitors (Surendran et al. 2005, Cheng et al. 2008, He et al. 2009, Henderson et al. 2010, He et al. 2011, Kim et al. 2011, Pfaff et al. 2011).

SFRPs have a cysteine-rich domain that can bind Wnt proteins and frizzled receptors and may perturb the Wnt-frizzled interaction to modulate the functions of Wnt proteins (Bovolenta et al. 2008). Recombinant sFRP4 reduced the amount of cytosolic and nuclear $\beta$-catenin within the tubular epithelium and altered the progression of renal fibrosis in UUO model (Surendran et al. 2005). Because of function as extracellular Wnt inhibitors, sFRPs can block both canonical and noncanonical Wnt signaling. Conversely, DKKs can specifically inhibit the Wnt/ $\beta$-catenin signaling by binding to the LRP5/6 component of the receptor complex (Mao et al. 2002). He et al. (2009) showed that delivery of DKK1 gene significantly reduced $\beta$-catenin accumulation, inhibited the expression of $\mathrm{Wnt} / \beta$-catenin target genes, and reduced total collagen content in the model of obstructive nephropathy. However, it was reported that only high concentrations of DKK1 could inhibit the WNT-induced proliferation of bronchial and alveolar epithelial cells, suggesting DKK1 may not be able to fulfil an effective negative feedback-loop on WNT-induced aberrant alveolar epithelial cell proliferation in IPF in vivo (Fig. 2) (Pfaff et al. 2011).

Paricalcitol, a synthetic, low-calcemic vitamin D analog, largely abolished the induction of multiple Wnt ligands and $\beta$-catenin (predominantly in podocytes and tubular epithelial cells), hampered activation of renal myofibroblasts, reduced glomerulosclerotic lesions and prevented proteinuria in adriamycin nephropathy (He et al. 2011). In addition, paricalcitol induced a physical interaction between the vitamin $\mathrm{D}$ receptor and $\beta$-catenin in podocytes in vitro (He et al. 2011). This action of vitamin $\mathrm{D}$ appears to be mediated by ligand-activated vitamin D receptor (VDR) competing with transcription factor TCF-4 for $\beta$-catenin binding (Fig. 2) (Shah et al. 2006). Additionally, administration of siRNA for $\beta$-catenin into trachea of mice significantly decreased the levels of collagen, MMP- 2 and TGF- $\beta$ expression in the lung tissue (Kim et al. 2011). In recent years, many small molecular compounds were identified as antagonists of the Wnt/ $\beta$-catenin pathway (Lepourcelet et al. 2004). ICG-001 is a unique small molecule, which selectively inhibits TCF/ $\beta$-catenin transcription through interacting with CBP and blocking the $\beta$-catenin/CBP interaction (Emami et al. 2004). More recently, ICG-001 was reported to significantly inhibit $\beta$-catenin signaling and attenuate renal interstitial fibrosis as well as bleomycininduced lung fibrosis (Fig. 2) (Henderson et al. 2010, Hao et al. 2011). Most importantly, the present findings may have clinical implications because some selective inhibitors of $\mathrm{Wnt} / \beta$-catenin signaling have recently entered clinical trials and would be available for patients in the future (www.clinicaltrials.gov).

\section{Conclusions}

As discussed above, aberrant $\mathrm{Wnt} / \beta$-catenin signaling reactivation in adult drives organ fibrosis by, for example, epithelial cell transformation or EMT, fibroblast proliferation and activation, or interaction with other profibrotic growth factors, altogether perpetuating fibrogenesis. In addition, Wnt signaling was identified as potential pathway through which microRNAs relevant to fibrosis progression. Given the $\mathrm{Wnt} / \beta$-catenin signaling is involved in fibrosis diseases, and encouragingly, now there is a variety of Wnt pathway inhibitors and some have recently entered clinical trials which give us the potential therapeutic feasibility, modulation of the Wnt pathway may, therefore, present as a suitable and promising therapeutic strategy in the future. Taken together, a better understanding of $\mathrm{Wnt} / \beta$-catenin signaling will offer new hopes for the treatment of fibrotic disorders.

\section{Conflict of Interest}

There is no conflict of interest.

\section{Acknowledgements}

This study is supported by National Basic Research Program of China 973 Program No. 2012CB517600 (No. 2012CB517601), National Nature Science Fund of China (No. 81101541 and NO. 81070610) and Key Clinical Program of the Ministry of Health in China (No. 2010439). 


\section{References}

BAYLE J, FITCH J, JACOBSEN K, KUMAR R, LAFYATIS R, LEMAIRE R: Increased expression of Wnt2 and SFRP4 in Tsk mouse skin: role of Wnt signaling in altered dermal fibrillin deposition and systemic sclerosis. J Invest Dermatol 128: 871-881, 2008.

BERGMANN C, AKHMETSHINA A, DEES C, PALUMBO K, ZERR P, BEYER C, ZWERINA J, DISTLER O, SCHETT G, DISTLER JH: Inhibition of glycogen synthase kinase 3beta induces dermal fibrosis by activation of the canonical Wnt pathway. Ann Rheum Dis 70: 2191-2198, 2011.

BIERNACKA A, DOBACZEWSKI M, FRANGOGIANNIS NG: TGF-beta signaling in fibrosis. Growth Factors 29: 196-202, 2011.

BOVOLENTA P, ESTEVE P, RUIZ JM, CISNEROS E, LOPEZ-RIOS J: Beyond Wnt inhibition: new functions of secreted Frizzled-related proteins in development and disease. J Cell Sci 121: 737-746, 2008.

BRACK AS, CONBOY MJ, ROY S, LEE M, KUO CJ, KELLER C, RANDO TA: Increased Wnt signaling during aging alters muscle stem cell fate and increases fibrosis. Science 317: 807-810, 2007.

CADIGAN KM, LIU YI: Wnt signaling: complexity at the surface. J Cell Sci 119: 395-402, 2006.

CHENG JH, SHE H, HAN YP, WANG J, XIONG S, ASAHINA K, TSUKAMOTO H: Wnt antagonism inhibits hepatic stellate cell activation and liver fibrosis. Am J Physiol Gastrointest Liver Physiol 294: G39-G49, 2008.

CHENG SL, SHAO JS, HALSTEAD LR, DISTELHORST K, SIERRA O, TOWLER DA: Activation of vascular smooth muscle parathyroid hormone receptor inhibits Wnt/beta-catenin signaling and aortic fibrosis in diabetic arteriosclerosis. Circ Res 107: 271-282, 2010.

CHEON SS, WEI Q, GURUNG A, YOUN A, BRIGHT T, POON R, WHETSTONE H, GUHA A, ALMAN BA: Betacatenin regulates wound size and mediates the effect of TGF-beta in cutaneous healing. Faseb J 20: 692-701, 2006.

CHIEN AJ, CONRAD WH, MOON RT: A Wnt survival guide: from flies to human disease. J Invest Dermatol 129: 1614-1627, 2009.

CHILOSI M, POLETTI V, ZAMO A, LESTANI M, MONTAGNA L, PICCOLI P, PEDRON S, BERTASO M, SCARPA A, MURER B, CANCELLIERI A, MAESTRO R, SEMENZATO G, DOGLIONI C: Aberrant Wnt/beta-catenin pathway activation in idiopathic pulmonary fibrosis. Am J Pathol 162: 1495-1502, 2003.

CHO JH, GELINAS R, WANG K, ETHERIDGE A, PIPER MG, BATTE K, DAKHALLAH D, PRICE J, BORNMAN D, ZHANG S, MARSH C, GALAS D: Systems biology of interstitial lung diseases: integration of mRNA and microRNA expression changes. BMC Med Genomics 4: 8, 2010.

CLEVERS H: Wnt/beta-catenin signaling in development and disease. Cell 127: 469-480, 2006.

DAI C, STOLZ DB, KISS LP, MONGA SP, HOLZMAN LB, LIU Y: Wnt/beta-catenin signaling promotes podocyte dysfunction and albuminuria. J Am Soc Nephrol 20: 1997-2008, 2009.

EGER A, STOCKINGER A, PARK J, LANGKOPF E, MIKULA M, GOTZMANN J, MIKULITS W, BEUG H, FOISNER R: beta-Catenin and TGFbeta signalling cooperate to maintain a mesenchymal phenotype after FosER-induced epithelial to mesenchymal transition. Oncogene 23: 2672-2680, 2004.

EMAMI KH, NGUYEN C, MA H, KIM DH, JEONG KW, EGUCHI M, MOON RT, TEO JL, KIM HY, MOON SH, HA JR, KAHN M: A small molecule inhibitor of beta-catenin/CREB-binding protein transcription [corrected]. Proc Natl Acad Sci US A 101: 12682-12687, 2004.

EZZIE ME, CRAWFORD M, CHO JH, ORELLANA R, ZHANG S, GELINAS R, BATTE K, YU L, NUOVO G, GALAS D, DIAZ P, WANG K, NANA-SINKAM SP: Gene expression networks in COPD: microRNA and mRNA regulation. Thorax 67: 122-131, 2010.

FRANKLIN TJ: Therapeutic approaches to organ fibrosis. Int J Biochem Cell Biol 29: 79-89, 1997.

GARDNER H, SHEARSTONE JR, BANDARU R, CROWELL T, LYNES M, TROJANOWSKA M, PANNU J, SMITH E, JABLONSKA S, BLASZCZYK M, TAN FK, MAYES MD: Gene profiling of scleroderma skin reveals robust signatures of disease that are imperfectly reflected in the transcript profiles of explanted fibroblasts. Arthritis Rheum 54: 1961-1973, 2006. 
GRIGORYAN T, WEND P, KLAUS A, BIRCHMEIER W: Deciphering the function of canonical Wnt signals in development and disease: conditional loss- and gain-of-function mutations of beta-catenin in mice. Genes Dev 22: 2308-2341, 2008.

HAO S, HE W, LI Y, DING H, HOU Y, NIE J, HOU FF, KAHN M, LIU Y: Targeted inhibition of beta-catenin/CBP signaling ameliorates renal interstitial fibrosis. J Am Soc Nephrol 22: 1642-1653, 2011.

HE W, DAI C, LI Y, ZENG G, MONGA SP, LIU Y: Wnt/beta-catenin signaling promotes renal interstitial fibrosis. J Am Soc Nephrol 20: 765-776, 2009.

HE W, KANG YS, DAI C, LIU Y: Blockade of Wnt/beta-catenin signaling by paricalcitol ameliorates proteinuria and kidney injury. J Am Soc Nephrol 22: 90-103, 2011.

HE W, TAN RJ, LI Y, WANG D, NIE J, HOU FF, LIU Y: Matrix metalloproteinase-7 as a surrogate marker predicts renal Wnt/beta-catenin activity in CKD. J Am Soc Nephrol 23: 294-304, 2012.

HEIKKILA E, JUHILA J, LASSILA M, MESSING M, PERALA N, LEHTONEN E, LEHTONEN S, SJEF VERBEEK J, HOLTHOFER H: beta-Catenin mediates adriamycin-induced albuminuria and podocyte injury in adult mouse kidneys. Nephrol Dial Transplant 25: 2437-2446, 2010.

HENDERSON WR JR, CHI EY, YE X, NGUYEN C, TIEN YT, ZHOU B, BOROK Z, KNIGHT DA, KAHN M: Inhibition of $\mathrm{Wnt} /$ beta-catenin/CREB binding protein (CBP) signaling reverses pulmonary fibrosis. Proc Natl Acad Sci U S A 107: 14309-14314, 2010.

HUANG H, HE X: Wnt/beta-catenin signaling: new (and old) players and new insights. Curr Opin Cell Biol 20: 119$125,2008$.

JIANG F, PARSONS CJ, STEFANOVIC B: Gene expression profile of quiescent and activated rat hepatic stellate cells implicates Wnt signaling pathway in activation. J Hepatol 45: 401-409, 2006.

KAMINSKI N, ROSAS IO: Gene expression profiling as a window into idiopathic pulmonary fibrosis pathogenesis: can we identify the right target genes? Proc Am Thorac Soc 3: 339-344, 2006.

KATO N, SHIMMURA S, KAWAKITA T, MIYASHITA H, OGAWA Y, YOSHIDA S, HIGA K, OKANO H, TSUBOTA K: Beta-catenin activation and epithelial-mesenchymal transition in the pathogenesis of pterygium. Invest Ophthalmol Vis Sci 48: 1511-1517, 2007.

KIM KK, WEI Y, SZEKERES C, KUGLER MC, WOLTERS PJ, HILL ML, FRANK JA, BRUMWELL AN, WHEELER SE, KREIDBERG JA, CHAPMAN HA: Epithelial cell alpha3beta1 integrin links beta-catenin and Smad signaling to promote myofibroblast formation and pulmonary fibrosis. J Clin Invest 119: 213-224, 2009.

KIM TH, KIM SH, SEO JY, CHUNG H, KWAK HJ, LEE SK, YOON HJ, SHIN DH, PARK SS, SOHN JW: Blockade of the Wnt/beta-catenin pathway attenuates bleomycin-induced pulmonary fibrosis. Tohoku J Exp Med 223: 45-54, 2011.

KONIGSHOFF M, BALSARA N, PFAFF EM, KRAMER M, CHROBAK I, SEEGER W, EICKELBERG O: Functional Wnt signaling is increased in idiopathic pulmonary fibrosis. PLoS One 3: e2142, 2008.

LAM AP, FLOZAK AS, RUSSELL S, WEI J, JAIN M, MUTLU GM, BUDINGER GR, FEGHALI-BOSTWICK CA, VARGA J, GOTTARDI CJ: Nuclear \{beta\}-catenin is increased in ssc pulmonary fibrosis and promotes lung fibroblast migration and proliferation. Am J Respir Cell Mol Biol, 45: 915-922, 2011.

LEPOURCELET M, CHEN YN, FRANCE DS, WANG H, CREWS P, PETERSEN F, BRUSEO C, WOOD AW, SHIVDASANI RA: Small-molecule antagonists of the oncogenic Tcf/beta-catenin protein complex. Cancer Cell 5: 91-102, 2004.

LI W, ZHU C, CHEN X, LI Y, GAO R, WU Q: Pokeweed antiviral protein down-regulates Wnt/beta-catenin signalling to attenuate liver fibrogenesis in vitro and in vivo. Dig Liver Dis 43: 559-566, 2011.

LIN CL, WANG JY, KO JY, HUANG YT, KUO YH, WANG FS: Dickkopf-1 promotes hyperglycemia-induced accumulation of mesangial matrix and renal dysfunction. J Am Soc Nephrol 21: 124-135, 2010.

LIU L, CARRON B, YEE HT, YIE TA, HAJJOU M, ROM W: Wnt pathway in pulmonary fibrosis in the bleomycin mouse model. J Environ Pathol Toxicol Oncol 28: 99-108, 2009.

MACDONALD BT, SEMENOV MV, HE X: SnapShot: Wnt/beta-catenin signaling. Cell 131: 1204, 2007.

MAO B, WU W, DAVIDSON G, MARHOLD J, LI M, MECHLER BM, DELIUS H, HOPPE D, STANNEK P, WALTER C, GLINKA A, NIEHRS C: Kremen proteins are Dickkopf receptors that regulate Wnt/beta-catenin signalling. Nature 417: 664-667, 2002. 
MASSZI A, FAN L, ROSIVALL L, MCCULLOCH CA, ROTSTEIN OD, MUCSI I, KAPUS A: Integrity of cell-cell contacts is a critical regulator of TGF-beta 1-induced epithelial-to-myofibroblast transition: role for betacatenin. Am J Pathol 165: 1955-1967, 2004.

MEDICI D, HAY ED, OLSEN BR: Snail and Slug promote epithelial-mesenchymal transition through beta-catenin-Tcell factor-4-dependent expression of transforming growth factor-beta3. Mol Biol Cell 19: 4875-4887, 2008.

MYUNG SJ, YOON JH, GWAK GY, KIM W, LEE JH, KIM KM, SHIN CS, JANG JJ, LEE SH, LEE SM, LEE HS: Wnt signaling enhances the activation and survival of human hepatic stellate cells. FEBS Lett 581: 2954-2958, 2007.

NOBLE PW: Idiopathic pulmonary fibrosis. New insights into classification and pathogenesis usher in a new era therapeutic approaches. Am J Respir Cell Mol Biol 29: S27-S31, 2003.

PANDIT KV, MILOSEVIC J, KAMINSKI N: MicroRNAs in idiopathic pulmonary fibrosis. Transl Res 157: 191-199, 2011.

PFAFF EM, BECKER S, GUNTHER A, KONIGSHOFF M: Dickkopf proteins influence lung epithelial cell proliferation in idiopathic pulmonary fibrosis. Eur Respir J 37: 79-87, 2011.

SAADI-KHEDDOUCI S, BERREBI D, ROMAGNOLO B, CLUZEAUD F, PEUCHMAUR M, KAHN A, VANDEWALLE A, PERRET C: Early development of polycystic kidney disease in transgenic mice expressing an activated mutant of the beta-catenin gene. Oncogene 20: 5972-5981, 2001.

SATO M: Upregulation of the Wnt/beta-catenin pathway induced by transforming growth factor-beta in hypertrophic scars and keloids. Acta Derm Venereol 86: 300-307, 2006.

SELMAN M, PARDO A, BARRERA L, ESTRADA A, WATSON SR, WILSON K, AZIZ N, KAMINSKI N, ZLOTNIK A: Gene expression profiles distinguish idiopathic pulmonary fibrosis from hypersensitivity pneumonitis. Am J Respir Crit Care Med 173: 188-198, 2006.

SELMAN M, PARDO A, KAMINSKI N: Idiopathic pulmonary fibrosis: aberrant recapitulation of developmental programs? PLoS Med 5: e62, 2008.

SHAH S, ISLAM MN, DAKSHANAMURTHY S, RIZVI I, RAO M, HERRELL R, ZINSER G, VALRANCE M, ARANDA A, MORAS D, NORMAN A, WELSH J, BYERS SW: The molecular basis of vitamin D receptor and beta-catenin crossregulation. Mol Cell 21: 799-809, 2006.

SURENDRAN K, SCHIAVI S, HRUSKA KA: Wnt-dependent beta-catenin signaling is activated after unilateral ureteral obstruction, and recombinant secreted frizzled-related protein 4 alters the progression of renal fibrosis. J Am Soc Nephrol 16: 2373-2384, 2005.

SURENDRAN K, SIMON TC, LIAPIS H, MCGUIRE JK: Matrilysin (MMP-7) expression in renal tubular damage: association with Wnt4. Kidney Int 65: 2212-2222, 2004.

TRENSZ F, HAROUN S, CLOUTIER A, RICHTER MV, GRENIER G: A muscle resident cell population promotes fibrosis in hindlimb skeletal muscles of mdx mice through the Wnt canonical pathway. Am J Physiol Cell Physiol 299: C939-C947, 2010.

VON TOERNE C, SCHMIDT C, ADAMS J, KISS E, BEDKE J, PORUBSKY S, GRETZ N, LINDENMEYER MT, COHEN CD, GRONE HJ, NELSON PJ: Wnt pathway regulation in chronic renal allograft damage. Am J Transplant 9: 2223-2239, 2009.

VON TOERNE C, BEDKE J, SAFI S, PORUBSKY S, GRETZ N, LOEWE R, NELSON PJ, GRONE HJ: Modulation of Wnt and Hedgehog Signaling Pathways Is Linked to Retinoic Acid-Induced Amelioration of Chronic Allograft Dysfunction. Am J Transplant 12: 55-68, 2012.

WANG D, DAI C, LI Y, LIU Y: Canonical Wnt/beta-catenin signaling mediates transforming growth factor-beta1driven podocyte injury and proteinuria. Kidney Int 80: 1159-1169, 2011.

WEI J, BHATTACHARYYA S, TOURTELLOTTE WG, VARGA J: Fibrosis in systemic sclerosis: emerging concepts and implications for targeted therapy. Autoimmun Rev 10: 267-275, 2011.

WEI J, MELICHIAN D, KOMURA K, HINCHCLIFF M, LAM AP, LAFYATIS R, GOTTARDI CJ, MACDOUGALD OA, VARGA J: Canonical Wnt signaling induces skin fibrosis and subcutaneous lipoatrophy: a novel mouse model for scleroderma? Arthritis Rheum 63: 1707-1717, 2011.

WILLIS BC, BOROK Z: TGF-beta-induced EMT: mechanisms and implications for fibrotic lung disease. Am J Physiol Lung Cell Mol Physiol 293: L525-L534, 2007. 
XIE T, LIANG J, GUO R, LIU N, NOBLE PW, JIANG D: Comprehensive microRNA analysis in bleomycin-induced pulmonary fibrosis identifies multiple sites of molecular regulation. Physiol Genomics 43: 479-487, 2011.

XIONG SD, YU K, LIU XH, YIN LH, KIRSCHENBAUM A, YAO S, NARLA G, DIFEO A, WU JB, YUAN Y, HO SM, LAM YW, LEVINE AC: Ribosome-inactivating proteins isolated from dietary bitter melon induce apoptosis and inhibit histone deacetylase-1 selectively in premalignant and malignant prostate cancer cells. Int J Cancer 125: 774-782, 2009.

ZHOU B, LIU Y, KAHN M, ANN DK, HAN A, WANG H, NGUYEN C, FLODBY P, ZHONG Q, KRISHNAVENI MS, LIEBLER JM, MINOO P, CRANDALL ED, BOROK Z: Interactions between beta-catenin and transforming growth factor-beta signaling pathways mediate epithelial-mesenchymal transition and are dependent on the transcriptional co-activator cAMP-response element-binding protein (CREB)-binding protein (CBP). J Biol Chem 287: 7026-7038, 2012. 